\title{
MHC Class II Gene Expression Signature
}

National Cancer Institute

\section{Source}

National Cancer Institute. MHC Class II Gene Expression Signature. NCI Thesaurus. Code C120017.

A gene expression profile that provides diagnostic information in diffuse large B-cell lymphoma. Loss of MHC class II expression is correlated with poor patient outcome. 